\title{
The influence of work salary and working hours on employee job satisfaction
}

\author{
Li Chongyu $^{1}$ \\ ${ }^{1}$ BeiJing JiaoTong University School of Economics and Management, Beijing, China
}

\begin{abstract}
With the continuous development of the human resource management system, the academic circle pays more and more attention to the research of employee satisfaction analysis. As one of the important factors affecting corporate performance, employee satisfaction has a significant impact on fully mobilizing employee enthusiasm. This article uses the China Family Panel Studies (CFPS) database to explore the impact of working hours characteristics and work salary characteristics on the job satisfaction of employees in stateowned enterprises and private enterprises through ordered logit regression methods. The results found that: weekly working hours and annual work income have a significant impact on these two types of employees. However, in-kind benefits and cash benefits only have a significant impact on employees of private enterprises. The one-way commute time only has a significant impact on the employees of state-owned enterprises. On this basis, this article puts forward two suggestions to improve the pertinence of welfare, strengthen the role of welfare incentives, and the government to formulate a labor standard law related to working hours, in order to improve employee job satisfaction.
\end{abstract}

\section{Introduction}

Facing the increasingly fierce competitive market of economic globalization, all enterprises must strive to improve their own competitiveness, strengthen their competitive advantages, enable them to develop and grow further. Employees' satisfaction with their jobs is one of the important factors that affect corporate performance. Tang believe that the work behavior of employees is not entirely determined by their own abilities, but is more affected by job satisfaction and work attitude ${ }^{[1]}$. Therefore, improving employee job satisfaction and fully mobilizing the enthusiasm of employees are the primary focus of an enterprise to enhance its competitiveness.

American psychologist Hoppock formally proposed in 1935 that job satisfaction is the psychological and physical satisfaction brought to employees by the work itself and the working environment ${ }^{[2]}$. Domestic scholars are doing more research on the factors affecting satisfaction. The first is to study the impact of differences in individual characteristics of employees on job satisfaction in addition to the company's own characteristics ${ }^{[3]}$; the second is to study the basic psychological variables such as value, commitment, and expectations related to individual emotional responses of employees ${ }^{[4]}$. For employees' job satisfaction, The win-win atmosphere of labor and capital can significantly improve the external job satisfaction of employees; the third is to examine the relationship between job satisfaction and job performance, turnover and absence, and life satisfaction ${ }^{[5]}$; the fourth is to study the impact of work as the object itself on satisfaction ${ }^{[6]}$.
However, there are few comparative studies on the satisfaction of employees of different ownership enterprises, but only by specific analysis of specific problems of different types of enterprises can it be of practical significance.

Therefore, from the perspective of enterprises with different ownerships, this article examines the effects of salary and time on job satisfaction of employees in stateowned enterprises and private or foreign-owned enterprises, and proposes practical policy recommendations on this basis.

\section{Materials and Methods}

The data in this article comes from the China Family Panel Studies (CFPS) database. The CFPS survey covers 25 provinces, municipalities, and autonomous regions across the country, and adopts a three-stage cluster sampling design with unequal probability, so the data can be regarded as a good representative national data. The data used in this paper is divided into the characteristic variables of personal endowment and the characteristic variables of working time and work salary in the experimental design.

\subsection{Research method}

The dependent variable "job satisfaction" in this study is ranked data, so the ordered logit method is used for regression. Hypothesise $y^{*}=x^{\prime} \beta+$ $\varepsilon\left(y^{*}\right.$ is unobservable $)$, 
The selection rule is $\mathrm{y}=\left\{\begin{array}{c}1, \quad \text { if } y^{*} \leq r_{0} \\ 2, \quad \text { if } r_{0}<y^{*} \leq r_{1} \\ J, \quad \text { if } r_{j-1} \leq y^{*}\end{array}\right.$

$r_{0}<r_{1}<\cdots<r_{j-1}$ is the parameter to be estimated

Hypothesise $\varepsilon \sim N(0,1)$, Standardize the variance of the disturbance term to 1 , then

$\mathrm{p}(y=1 \mid x)=p\left(y^{*} \leq r_{0} \mid x\right)=p\left(x^{\prime} \beta+\varepsilon \leq r_{0} \mid x\right)=$

$p\left(\varepsilon \leq r_{0}-x^{\prime} \beta \mid x\right)=\varphi\left(r_{0}-x^{\prime} \beta\right)$

$\mathrm{p}(y=2 \mid x)=p\left(r_{0}<y^{*} \leq r_{1} \mid x\right)$

$=p\left(x^{\prime} \beta+\varepsilon \leq r_{1} \mid x\right)-\varphi\left(r_{0}-x^{\prime} \beta\right)$

$=p\left(\varepsilon \leq r_{1}-x^{\prime} \beta \mid x\right)-\varphi\left(r_{0}-x^{\prime} \beta\right)=\varphi\left(r_{1}-x^{\prime} \beta\right)$

$\varphi\left(r_{0}-x^{\prime} \beta\right)$

$\mathrm{p}(y=J \mid x)=1-\varphi\left(r_{j-1}-x^{\prime} \beta\right)$

\subsection{Construction the empirical Model}

Set the ordered Logit model of job satisfaction as

$$
\begin{gathered}
\text { Logit }=\alpha_{j}+\beta_{1} x_{1}+\beta_{2} x_{2}+\beta_{3} x_{3}+\beta_{4} x_{4}+\beta_{5} x_{5} \\
+\beta_{6} p_{1}+\beta_{7} p_{2}+\mu
\end{gathered}
$$

Among them, the explanatory variables are the job satisfaction of the respondent; the explanatory variables include the personal characteristics of the respondent, gender, age, and the characteristics of the respondent's working hours, the one-way commute time, weekly working hours, and the interviewee's personal characteristics. The characteristics of workers' salary is the annual salary, whether there are cash benefits, and whether there are in-kind benefits. $\mathrm{u}$ is the random error term representing random influencing factors outside the model.

\begin{tabular}{|c|c|c|c|c|}
\hline Variable type & Variable name & Indicator name & Symbol & Description \\
\hline $\begin{array}{l}\text { Dependent } \\
\text { variable }\end{array}$ & & job satisfaction & $\mathrm{Y}$ & $\begin{array}{c}\text { Very dissatisfied }=1, \text { Not so satisfied }=2 \text {, } \\
\text { Generally satisfied }=3 \text {, Quite satisfied }=4 \text {, } \\
\text { Very satisfied }=5\end{array}$ \\
\hline \multirow{7}{*}{$\begin{array}{l}\text { Independent } \\
\text { variable }\end{array}$} & \multirow{2}{*}{ characteristics } & gender & $\mathrm{P} 1$ & male $=1$, female $=0$ \\
\hline & & age & $\mathrm{P} 2$ & age \\
\hline & \multirow{2}{*}{$\begin{array}{l}\text { Working time } \\
\text { characteristics }\end{array}$} & $\begin{array}{l}\text { one-way } \\
\text { commute time }\end{array}$ & $\mathrm{X} 1$ & minute \\
\hline & & $\begin{array}{l}\text { weekly working } \\
\text { hours }\end{array}$ & $\mathrm{X} 2$ & hour \\
\hline & \multirow{3}{*}{$\begin{array}{c}\text { Job salary } \\
\text { characteristics }\end{array}$} & annual salary & $\mathrm{X} 3$ & Ten thousand yuan \\
\hline & & cash benefits & $\mathrm{X} 4$ & yes $=1$, no $=0$ \\
\hline & & in-kind benefits & $\mathrm{X} 5$ & yes $=1$, no $=0$ \\
\hline
\end{tabular}

Table 1.Variable definitions

\section{Results \& Discussion}

Table2. Regression results

\begin{tabular}{ccc}
\hline & $\begin{array}{c}\text { State-owned } \\
\text { enterprise }\end{array}$ & $\begin{array}{c}\text { Private or } \\
\text { foreign } \\
\text { companies }\end{array}$ \\
\hline gender & $-0.3298^{* *}$ & $-0.2089^{* * *}$ \\
age & $0.1337)$ & 0.0535 \\
one-way commute & -0.0062 & $0.0085^{* * *}$ \\
time & $(0.0025)$ & $(0.0021)$ \\
weekly working & $-0.0078^{* *}$ & $-0.01471 * * *$ \\
hours & $(0.0038)$ & $(0.0015)$ \\
annual salary & $0.0435^{* * *}$ & $0.03416^{* * *}$ \\
cash benefits & $(0.0161)$ & $(0.0081)$ \\
in-kind benefits & 0.1743 & $0.3356^{* * *}$ \\
& $(0.1271)$ & $(0.0618)$ \\
\hline
\end{tabular}

Note: $*$ means significant at the $10 \%$ level, ** means significant at the $5 \%$ level, $* * *$ means significant at the $1 \%$ level, and the standard errors are in parentheses.
1. In the two types of samples of state-owned enterprises, private or foreign enterprises, gender significantly affects job satisfaction. Among them, female employees have higher job satisfaction, and male employees have lower job satisfaction.

2. In this type of sample of private or foreign companies, age significantly affects job satisfaction. Among them, the older the age, the higher the job satisfaction. For the sample of state-owned enterprises, the effect of age on job satisfaction is not significant.

3. In this type of sample of state-owned enterprises, the one-way commute time significantly affects job satisfaction. The longer the one-way commute time, the lower the job satisfaction. For samples of private or foreign companies, the impact of one-way commuting time on job satisfaction is not significant.

4. In the two types of samples of state-owned enterprises, private enterprises or foreign enterprises, working hours per week significantly affect job satisfaction. Among them, the longer the weekly working hours, the lower the job satisfaction, and the shorter the weekly working hours, the higher the job satisfaction.

5 . In the two types of samples of private or foreign enterprises and state-owned enterprises, annual job income significantly affects job satisfaction. Among them, the higher the annual work income, the higher the job 
satisfaction.

6. In this type of sample of private or foreign companies, the presence or absence of cash or in-kind benefits significantly affects job satisfaction. Among them, employees who receive cash or in-kind benefits are highly satisfied with their jobs. For state-owned enterprises, the presence or absence of cash or in-kind benefits does not have a significant impact on job satisfaction.

\section{Conclusion and suggestion}

Through the analysis of the above two different types of employees' job satisfaction, it is found that weekly working hours have a significant impact on the job satisfaction of the two types of employees. In today's period of rapid economic development, corporate executives will squeeze the interests of employees as much as possible in order to bring higher returns to the enterprise. The 996 and 007 work systems are jawdropping. Excessive working hours will reduce the professional happiness of workers. Workers have to passively increase their labor intensity in the face of fierce competition for talents in order to avoid being dismissed by enterprises. For state-owned enterprises, the competition within the organization is also very fierce. Under the premise of not being dismissed by the unit, workers have the desire to be promoted. Under this goal, workers also have to increase their working hours. The excessively high housing prices in the central city have to force workers to rent houses in suburban areas far away from their work units, which greatly increases the travel time to and from get off work, and in a disguised way increases the cost of labor for workers. Workers need to get up early every day to get to work on time, and it takes a long time to go home smoothly after working overtime at night. Excessive commuting time will undoubtedly reduce employee satisfaction with work. For employees of state-owned enterprises, due to shorter overtime hours per week, longer one-way commuting time will significantly reduce employee job satisfaction.

Salary includes wages, benefits in kind, cash benefits and other forms. For state-owned enterprise employees, the variable annual salary significantly affects the job satisfaction of state-owned enterprise employees, while in-kind benefits and cash benefits have no significant effect on state-owned enterprise employee satisfaction. This may be due to the relatively low pressure of competition among employees of state-owned enterprises. In this context, common job benefits cannot have a positive effect on employees. For private and foreign companies, annual wages, in-kind benefits, and cash benefits can significantly affect employee job satisfaction. This may be due to the greater competition pressure of private foreign companies and longer working hours. The company provides employees with benefits that can make them feel the warmth of the company. Benefits can significantly positively regulate the win-win atmosphere of labor and capital and positively affect external job satisfaction. The higher the level of welfare, the stronger the positive impact of the labor-management win-win atmosphere on external job satisfaction.
Based on the above conclusions, the following suggestions are made to achieve the effect of improving employee satisfaction

\subsection{The government formulates labor standards laws related to working hours}

In recent years, the 996 and 007 work systems have become more and more common and have become a normal work system. In an increasingly competitive environment, enterprises can only constantly squeeze the rights and interests of employees. Under the pressure of fear of being fired and fined, employees have to accept endless overtime. Excessive working hours have caused great threats to the health of employees. Death from overwork has become more common social news. In this context, the government should actively manage the social phenomenon of overwork, formulate labor standards laws related to working hours, protect employee groups, shorten their working hours, improve the physical and mental health of workers, and increase their work efficiency and work happiness.

\subsection{Improve welfare pertinence}

Companies should give full consideration to the actual needs of employees, and formulate appropriate welfare policies based on the needs of employees, so as to better improve the positive effects of welfare policies, and increase employees' loyalty to the organization and job satisfaction. On the one hand, companies can formulate employee welfare needs survey forms, and employees can use effective methods to transmit their own demand signals, so that the senior management can fully understand, and they can formulate a welfare system that better meets the needs of employees. On the other hand, when the company adjusts the new round of welfare policies, it should collect employees' satisfaction with the previous round of welfare policies and the areas they hope to improve. This will help the company formulate welfare policies that make employees more satisfied and improve their work, so as to enhance corporate profitability and core competitiveness.

\section{Acknowledgments}

Thanks to the tutor and teachers who helped me along the way. They not only provided us with a good academic atmosphere, but also influenced us with their own rigorous academic attitude and high-clean character, and guided us forward like a beacon. Finally, I would like to thank the senior academics who have guided me academically and cherished me in life, and thank my parents, family and friends for their all-round support and encouragement.

\section{References}

1. Don Holrigger, John W. Sluckham Jr., Richard W. Wardman. (2001). Organizational Behavior [M]. Dalian: Dongbei University of Finance and 
Economics Press, 67-72 .

2. Hoppock, Robert. (1935) Job Satisfaction. Oxford, England: Harper.

3. Wang Zhigang, Jiang Huiming. (2004). An Empirical Study on the Influence of Individual Characteristics of Chinese Employees on Corporate Satisfaction [J]. Nankai Management Review, (01): 101-106.

4. Cui Xun, Zhang Yiming, Qu Jiaojiao. (2012). Labor relations atmosphere and employee job satisfaction: the moderating effect of organizational commitment [J]. Nankai Management Review, 15(02): 19-30.

5. Ye Rensun, Wang Yuqin, Lin Zeyan. (2005). An Empirical Study on the Impact of Job Satisfaction and Organizational Commitment on State-owned Enterprise Employees' Turnover[J]. Management World, (03): 122-125.

6. Huang Gui. (2005) An Empirical Study on the Influencing Factors of Employee Satisfaction[J]. Management World, (11): 160-161. 